\title{
Proses berpikir kreatif siswa dalam memecahkan masalah matematika berdasarkan model Wallas
}

\author{
Agus Purnama Sari, M.Ikhsan, Saminan ${ }^{1}$
}

\begin{abstract}
Abstrak: Penelitian kualitatif ini bertujuan untuk mengetahui proses berpikir kreatif siswa dalam memecahkan masalah matematika berdasarkan model Wallas (1926). Subjek penelitian terdiri dari 6 siswa kelas VII, masing-masing dua siswa memiliki kemampuan matematika tinggi, sedang, dan rendah. Pengumpulan data dilakukan dengan menggunakan tes dan wawancara. Hasil penelitian menunjukkan bahwa proses berpikir kreatif siswa kategori tinggi yaitu siswa memahami permasalahan dan informasi yang diberikan dengan menuliskan apa yang diketahui maupun yang ditanyakan (persiapan), siswa tidak membutuhkan waktu yang lama untuk memikirkan solusi dari permasalahan yang dihadapi dengan mengingat soal yang sudah diajarkan (inkubasi), siswa mendapatkan ide untuk memecahkan masalah (lluminasi), dan siswa menguji ide dan memeriksa kembali pemecahan masalah sebelum mengambil kesimpulan yang tepat (verifikasi). Proses berpikir kreatif siswa kategori sedang yaitu siswa mencoba untuk memahami permasalahan akan tetapi kurang memahami informasi atau petunjuk yang diberikan (persiapan), siswa diam megingat kembali rumus yang digunakan untuk memecahkan masalah (Inkubasi), siswa menghasilkan ide berdasarkan pemahamannya terhadap soal untuk memecahkan masalah (Iluminasi), dan siswa menguji ide dihasilkan dan tidak memeriksa kembali proses pemecahan masalah (verifikasi). Proses berpikir kreatif siswa kategori rendah yaitu siswa tidak memahami permasalahan dan informasi yang diberikan (persiapan), siswa membutuhkan waktu yang lama untuk memikirkan solusi dari permasalahan (Inkubasi), siswa gagal dalam menemukan ide untuk memecahkan permasalahan (Iluminasi), dan siswa menguji ide yang dihasilkan dan tidak memeriksa kembali jawaban yang telah diujikan (verifikasi).
\end{abstract}

Kata kunci: Berpikir Kreatif; Model Wallas; Pemecahan Masalah; Kemampuan Siswa

Abstract: This qualitative research aims at getting insight on students' creative thinking in solving mathematics problems based on Wallas' model (1926). The subjects are six students in $7^{\text {th }}$ grade, each two

\footnotetext{
1 Universitas Syiah Kuala, Aceh, Indonesia, purnamasaza@gmail.com
} 
students respectively have high, medium and low mathematics ability. Data is collected through test and interview. This research shows that the students in high category can understand the problem and given information by writing what is known and asked (preparation), can easily think the solution of the problem by remembering the previous problem (incubation), get the ideas to solve the problem (illumination), and examine the ideas and re-check the solution before drawing the proper conclusion (verification). The students in medium category try to understand the problem but they are less in understanding the given information or hint (preparation), remember the formula to solve the problem (incubation), generate the ideas from their understanding to solve the problem (illumination), and examine the ideas and do not check the solution again (verification). For students in low category, they do not understand the problem and the given information (preparation), have a while to think the solution (incubation), fail to find any ideas to solve the problem (illumination), and examine the generated ideas and do not re-check the solution (verification).

Keywords: Creative Thinking; Walla's Model; Problem Solving; Students'Ability

\section{A. Pendahuluan}

Kreativitas merupakan salah satu kemampuan berpikir tingkat tinggi, yang sampai saat ini masih kurang mendapatkan perhatian dalam pembelajaran matematika. Guru tidak menggali kreativitas siswa dalam memecahkan masalah dikarenakan permasalahan yang diberikan hanya memiliki satu jawaban yang benar. Guru tidak terbiasa mengajarkan permasalahan matematika yang memiliki jawaban benar lebih dari satu. Hal ini mengakibatkan siswa kurang berminat dalam memecahkan masalah matematika yang menuntut kreativitas. Padahal, jika diperhatikan Kurikulum 2013 menyatakan bahwa pendidikan bertujuan untuk mempersiapkan manusia Indonesia agar memiliki kemampuan hidup sebagai pribadi dan warga negara yang produktif, kreatif, inovatif, dan efektif. Berdasarkan tujuan tersebut salah satu kemampuan yang ingin dicapai adalah kemampuan berpikir kreatif.

Berpikir kreatif menurut Krulik (1995) berada pada tingkatan tertinggi berpikir secara nalar yang tingkatnya di atas berpikir mengingat (recall). Dalam penalaran terdapat berpikir dasar (basic), berpikir kritis (critical), dan berpikir kreatif. Kreativitas erat kaitannya dengan proses berpikir 
kreatif, dan proses berpikir kreatif erat kaitannya dengan proses mencipta. Siswono (2004) menyatakan bahwa mencipta memiliki arti meletakkan elemen-elemen secara bersama-sama untuk membentuk suatu keseluruhan yang berkaitan dan fungsional atau mengatur kembali elemen-elemen ke dalam suatu pola-pola baru. Mencipta dikaitkan dengan tiga proses kognitif, yaitu pembangkitan (generating), perencanaan (planning) dan menghasilkan (producing). Tiga proses kognitif tersebut identik dengan proses berpikir kreatif, salah satunya proses berpikir kreatif.

Proses berpikir kreatif merupakan suatu proses yang mengkombinasikan berpikir logis dan berpikir divergen. Berpikir divergen digunakan untuk mencari ide-ide untuk menyelesaikan masalah sedangkan berpikir logis digunakan untuk memverifikasi ide-ide tersebut menjadi sebuah penyelesaian yang kreatif (Siswono, Rosyidi \& Haris, 2005). Proses berpikir kreatif yang dikembangkan oleh Wallas (1926) merupakan salah satu teori yang paling umum dipakai untuk mengetahui proses berpikir kreatif yang meliputi empat tahap yaitu tahap persiapan, tahap inkubasi, tahap iluminasi, dan tahap verifikasi.

Pada tahap persiapan siswa mempersiapkan diri untuk memecahkan masalah dengan cara mengumpulkan data yang relevan dari pengalaman sebelumnya maupun pengetahuan yang baru, serta bertanya kepada orang lain untuk menyelesaikannya. Pada tahap inkubasi, siswa seakanakan melepaskan diri secara sementara dari masalah tersebut. Tetapi "mengeramnya" dalam pra-sadar. Pada tahap iluminasi, yaitu tahap dimana timbulnya inspirasi, dan ide-ide yang mengawali dan mengikuti munculnya inspirasi dan gagasan baru. Pada tahap terakhir adalah tahap seseorang menguji dan memeriksa pemecahan masalah tersebut terhadap realitas. Disini diperlukan pemikiran kritis dan konvergen. Pada tahap verifikasi ini seseorang setelah melakukan berpikir kreatif maka harus diikuti dengan berpikir kritis (Munandar, 2009).

Informasi terhadap proses berpikir kreatif menurut Siswono dkk (2005) akan memberikan gambaran tingkat berpikir kreatif peserta didik yang berguna bagi perancangan langkah-langkah pembelajaran untuk mendorong dan meningkatkan kreativitas peserta didik. Dalam dunia pendidikan, salah satu mata pelajaran yang penting untuk dipelajari oleh siswa adalah matematika. Pada pembelajaran matematika, pemecahan 
masalah merupakan aktivitas yang penting. Adapun Kaur (1997) menyatakan bahwa kemampuan pemecahan masalah merupakan jantung dari matematika. Pemecahan masalah matematika berhubungan erat dengan berpikir kreatif. Haylock (1997) menjelaskan bahwa pemecahan masalah bisa dijadikan penugasan yang dapat menggambarkan proses berpikir kreatif siswa. Pehkonen (1999) juga mengungkapkan bahwa dengan memecahkan masalah matematika dapat meningkatkan kreativitas matematika siswa.

Penelitian tentang kreativitas siswa dalam matematika telah banyak dilakukan (misalnya, Siswono \& Kurniawati, 2004). Penelitian tersebut melihat kemampuan pengajuan masalah sebagai suatu kemampuan kreatif. Produk pengajuan masalah ditinjau dengan menggunakan kriteria kreativitas, yaitu kefasihan (fluency), fleksibilitas (flexibility) dan kebaruan (originality), serta pada aspek proses kreatifnya yang menekankan pada segi kognitif siswa ketika memecahkan dan mengajukan masalah. Hasil penelitian menunjukkan bahwa dalam proses berfikir kreatif, masingmasing siswa pada kelompok tingkatan kreativitas yaitu kelompok kreatif, kurang kreatif dan tidak kreatif memiliki karakteristik yang berbeda dalam tiap tahapan proses berpikir. Penelitian tersebut memberikan bukti empirik hubungan antara berpikir kreatif dengan pemecahan dan pengajuan masalah matematika.

Kemampuan berpikir tingkat tinggi siswa di Indonesia khususnya dalam matematika masih tergolong rendah. Hal ini dapat dilihat pada Program for International Student Assessment (PISA) dalam kemampuan membaca, matematika dan ilmu pengetahuan dan teknologi (IPTEK) secara keseluruhan. Hasil PISA menempatkan Indonesia pada peringkat 62 dari 70 negara (OECD, 2016). Salah satu yang menyebabkan rendahnya kemampuan berpikir tingkat tinggi yaitu rendah dan kurangnya perhatian terhadap kreativitas di sekolah terutama dalam pembelajaran matematika. Sedangkan proses berpikir kreatif merupakan suatu proses yang dilalui siswa untuk menghasilkan ide atau gagasan (kreativitas) dalam memecahkan masalah.

Berdasarkan uraian di atas, maka tulisan ini akan menjawab pertanyaan bagaimanakah proses berpikir kreatif siswa dalam memecahkan masalah matematika berdasarkan tahapan Wallas (1926)? 


\section{B. Metode Penelitian}

Pendekatan yang digunakan dalam penelitian ini adalah deskriptif kualitatif, yang berupaya untuk mendeskripsikan proses berpikir kreatif siswa dalam dalam memecahkan masalah matematika berdasarkan tahapan Wallas. Penelitian ini dilaksanakan di MTsN Model Banda Aceh. Subjek dalam penelitian ini adalah siswa kelas VII-6 yang terdiri dari 16 laki-laki dan 20 perempuan. Subjek dalam penelitian ini dipilih berdasarkan hasil tugas pemecahan masalah.

Adapun prosedur pemilihan subjek penelitian yaitu: (1) memberikan tugas pemecahan masalah kepada seluruh subjek penelitian; (2) menganalisis hasil tugas dan selanjutnya mengelompokkan subjek ke dalam tiga kategori tinggi, sedang, dan tinggi; (4) memilih subjek yang merepresentasikan jawaban dari masing-masing kelompok jawaban secara purposive, yaitu berdasarkan kecukupan informasi atau data yang diperlukan; (5) subjek yang dipilih selanjutnya diwawancarai untuk memverifikasi data hasil tugas pemecahan masalah dan menggali data tentang proses berpikir kreatif dari masing-masing subjek penelitian. Instrumen penelitian terdiri dari instrumen utama yaitu peneliti sendiri, soal tes pemecahan masalah dan pedoman wawancara.

Untuk mengumpulkan data digunakan tes dan wawancara. Tes yang dilakukan dalam penelitian ini adalah tes pemecahan masalah. Soal terdiri dari lima soal uraian pada materi Pertidaksamaan Linear Satu Variabel (PtLSV). Wawancara dalam penelitian ini adalah wawancara semi terstruktur yang digunakan untuk memverifikasi hasil jawaban tes pemecahan masalah kemudian dianalisis sehingga didapat proses berpikir kreatif siswa dalam memecahkan masalah matematika. Teknik analisis data dalam penelitian ini menggunakan reduksi data, penyajian data, dan verifikasi atau kesimpulan.

\section{Temuan dan Pembahasan}

Hasil analisis data tugas pemecahan masalah, proses berpikir kreatif siswa dalam memecahkan masalah matematika berdasarkan tahapan yang dikembangkan oleh Wallas (1926), pada siswa kategori tinggi menunjukkan bahwa pada tahap persiapan, siswa memahami 
permasalahan dan mengetahui informasi yang dibutuhkan untuk memecahkan permasalahan yang dihadapi.

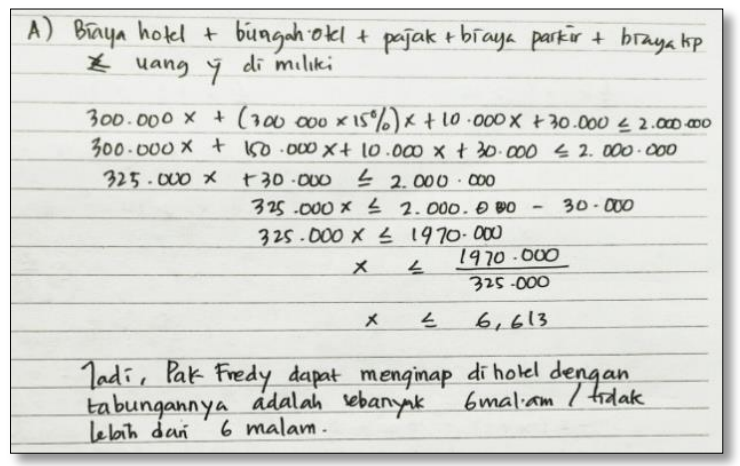

Gambar 1. Hasil Kerja Siswa Kategori Tinggi

Hal ini sesuai dengan petikan wawancara berikut:

P : Dapatkah kamu menjelaskannya? Apa yang kamu pahami dari soal tersebut?

S : Bisa

$\mathrm{P} \quad$ : Bagaimana kamu bisa mempunyai ide menjawab seperti ini?

$\mathrm{S} \quad$ : Berdasarkan soalnya, Fredy mau membayar keperluannya berlibur, ada biaya hotel, parkir, pajak, jadi ditotalkan semuanya.

Pada tahap inkubasi, siswa tidak membutuhkan waktu yang lama dan tidak mengalami kesulitan untuk menemukan solusi dalam memecahkan permasalahan yang diberikan. Hal ini sesuai dengan petikan wawancara berikut:

$\mathrm{P} \quad$ : Apa yang kamu pikirkan atau pertimbangkan sehingga menjawab seperti ini?

S : Informasi yang diberikan pada soal, dan soal-soal yang sudah pernah dibahas sebelumnya

$\mathrm{P} \quad$ : Apa kamu kesulitan dalam menemukan ide untuk menyelesaikannya?

S : Tidak

Pada tahap iluminasi, siswa menghasilkan ide untuk diterapkan dalam memecahkan permasalahan yang diberikan. Ide yang didapatkan 
diperoleh dengan mengingat soal-soal yang sudah pernah dibahas sebelumnya. Hal ini sesuai dengan petikan wawancara berikut:

$\mathrm{P} \quad$ : Dapatkah kamu menjelaskan yang sudah kamu kerjakan?

S : Bisa

$\mathrm{P} \quad$ : Kamu yakin sama jawaban kamu?

S : Yakin

$\mathrm{P} \quad$ : Apakah kamu langsung menuliskan jawabannya pada kertas?

S : lya

Pada tahap verifikasi, siswa menguji ide yang pertama kali terlintas dipikirannya pada kertas yang telah disediakan, meyakini jawabannya dengan memahami kembali apa yang diinginkan oleh soal. Hal ini sesuai dengan petikan wawancara berikut:

P : : Apa jawaban ini hasil pemikiran kamu pertama kali setelah membaca soal?

S : lya

$\mathrm{P} \quad$ : Apa yang harus dipertimbangkan dalam memecahkan permasalahan ini?

S $\quad$ : Yang diketahui dari soal, informasi yang diberikan

Proses berpikir kreatif siswa dalam memecahkan masalah matematika pada kategori sedang, berdasarkan hasil analisis data pemecahan masalah menjukkan bahwa pada tahap persiapan, siswa tidak dapat memahami permasalahan yang diberikan, dan juga tidak dapat menggunakan informasi yang diberikan untuk memecahkan permasalahan yang dihadapi.

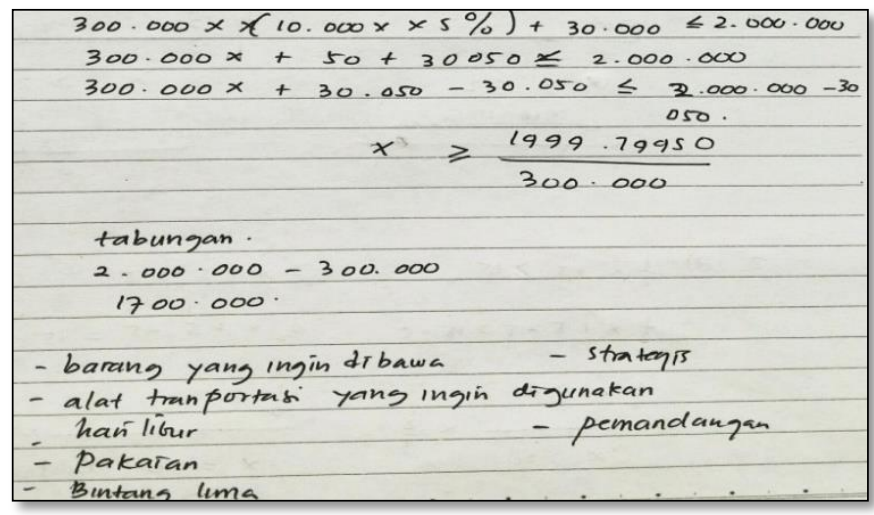




\section{Gambar 2. Hasil Kerja Siswa Kategori Sedang}

Hal ini sesuai dengan petikan wawancara berikut:

P : : Apa yang kamu pahami? Dapatkah kamu menjelaskannya?

$\mathrm{S}$ : Tidak tahu

$\mathrm{P} \quad$ : Atau mungkin kamu mempunyai cara sendiri? Dapatkah kamu menyelesaikannya?

S : Berkoma

$\mathrm{P} \quad$ : Apa kamu paham?

$\mathrm{S} \quad$ : Tidak

Pada tahap inkubasi, siswa mengalami kesulitan dalam memikirkan solusi dari permasalahan yang diberikan, dia membutuhkan waktu yang lama untuk berpikir. Hal ini sesuai dengan petikan wawancara berikut ini:

P : Bagaimana dengan model matematikanya? Dapatkah kamu menjelaskannya?

$\mathrm{S} \quad$ : Tidak

P : Kamu paham?

$\mathrm{S} \quad$ : Tidak

$\mathrm{P} \quad$ : Apa kamu kesulitan menemukan ide untuk menyelesaikannya?

S : lya, banyak angkanya

Pada tahap iluminasi, siswa menghasilkan ide untuk memecahkan masalah berdasarkan pemahamannya terhadap masalah yang dihadapi. Ide yang dihasilkan dengan mengingat contoh yang sudah pernah diajarkan. Hal ini sesuai dengan petikan wawancara berikut:

P : : Apa kesulitan kamu memecahkan masalah ini?

$\mathrm{S} \quad$ : Soalnya panjang, sulit untuk berpikir, saya tidak sanggup

$\mathrm{P} \quad$ : Apa yang kamu bayangkan atau pikirkan sehingga timbul ide seperti ini?

S : Saya mencoba mengingat apa yang sudah diajarkan

Pada tahap verifikasi, siswa menguji ide yang dihasilkannya untuk mendapatkan jawaban yang benar. Akan tetapi jawaban yang dihasilkan 
tidak benar, karena terjadi kekeliruan dalam proses penyelesaiannya. Hal ini sesuai dengan petikan wawancara berikut:

P : Pertama kali membaca soal, apakah ide tersebut yang terlintas di pikiranmu?

$\mathrm{S}:$ : ya

$\mathrm{P} \quad$ : Apa yang kamu lakukan dalam memecahkan permasalahan ini?

S : Berusaha untuk memahami soalnya, tapi saya tidak paham

Proses berpikir kreatif siswa dalam memecahkan masalah matematika pada kategori rendah, berdasarkan hasil analisis data pemecahan masalah menunjukkan bahwapada tahap persiapan, Meskipun sudah mencoba membaca ulang, akan tetapi siswa tidak dapat memahami permasalahan yang diberikan.

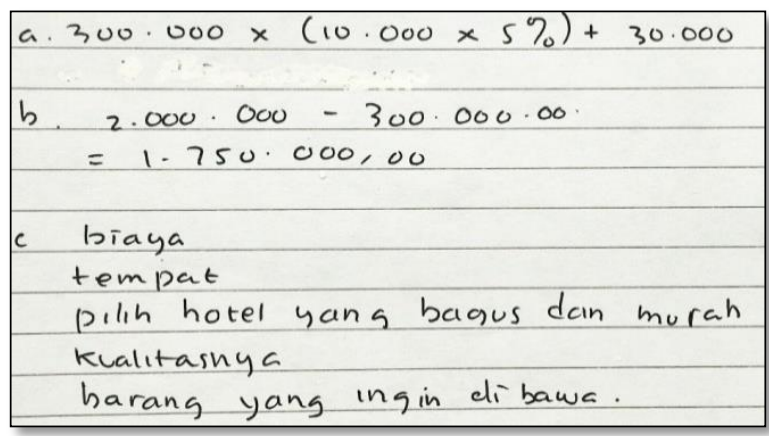

Gambar 3. Hasil Kerja Siswa Kategori Rendah

Hal ini sesuai dengan petikan wawancara berikut:

$\mathrm{P} \quad$ : Apa yang kamu pahami?

S : Yang C saja saya paham

P : Dari soalnya apa yang kamu pahami?

S : Dua juta

P : Apa kesulitan kamu dalam memecahkan masalah ini?

S : Saya tidak paham harus menggunakan cara apa

Pada tahap inkubasi, siswa menggaruk-garukkan kepalanya saat memikirkan solusi untuk memecahkan permasalahan, dan membutuhkan waktu yang lama. Hal ini sesuai dengan petikan wawancara berikut: 


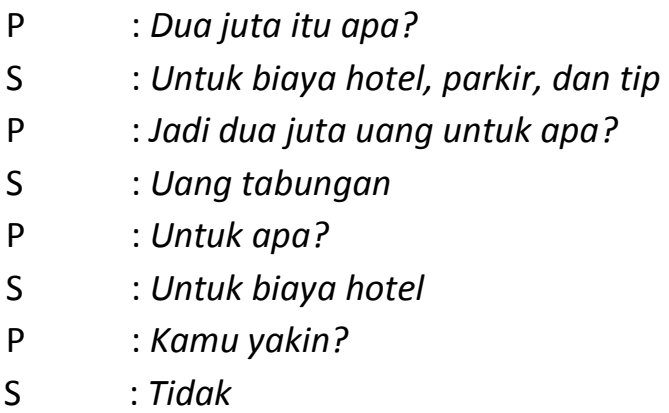

Pada tahap iluminasi, siswa menghasilkan ide yang tidak lengkap dan memberikan ide berdasarkan pemahaman terhadap soal, dengan mengingat materi yang sudah diajarkan dalam memecahkan masalah yang diberikan. Hal ini sesuai dengan petikan wawancara berikut:
P : Dalam memecahkan masalah ini, apa yang kamu lakukan?
$\mathrm{S} \quad$ : Membaca soalnya, lalu langsung menyelesaikannya
$\mathrm{P} \quad$ : Apa yang kamu bayangkan atau pikirkan sehingga timbul ide seperti ini?
$\mathrm{S} \quad$ : Saya mencoba mengingat apa yang sudah diajarkan
$\mathrm{P} \quad$ : Kamu yakin dengan jawaban kamu ini?
S : :Tidak

Pada tahap verifikasi, siswa menguji ide yang dihasilkan untuk mendapatkan jawaban yang relevan dengan permasalahan yang diberikan. Namun, jawaban yang diberikan tidak selesai, dikarenakan siswa tidak dapat mengumpulkan informasi dengan benar. Hal ini sesuai dengan petikan wawancara berikut:
P : Kamu paham?
$\mathrm{S} \quad$ : Tidak
$\mathrm{P} \quad$ : Jadi mengapa bisa menjawab seperti ini?
S : : Saya jawab asal saja
P : : Pertama kali membaca soal, apakah ide tersebut yang terlintas di pikiranmu?
S : lya 
Berdasarkan hasil analisis data pemecahan masalah dan wawancara siswa terhadap proses berpikir kreatif siswa dalam memecahkan permasalahan pada materi PtLSV, yang dilakukan setelah tes menunjukkan bahwa siswa pada kategori tinggi pada tahap persiapan, siswa telah mempersiapkan diri terlebih dahulu, dengan mengulang latihan soal-soal yang pernah diajarkan, memahami permasalahan dengan baik terlihat siswa menuliskan informasi yang diberikan dengan bahasanya sendiri. Hal ini juga sesuai dengan penelitian Wulantina, Kusmayadi, dan Riyadi (2015) yang menyimpulkan bahwa siswa dengan kemampuan tinggi pada tahap persiapan siswa mengidentifikasi masalah yang ditanyakan dengan baik, siswa memilih informasi yang dibutuhkan dan informasi yang tidak dibutuhkan dalam penyelesaian masalah dengan tepat. Kemudian pada tahap inkubasi siswa cenderung diam dengan memperhatikan informasi yang ada pada soal dan tidak membutuhkan waktu yang lama untuk menemukan solusi dari permasalahan yang dihadapi, dengan mengingat materi-materi yang sudah diajarkan. Ekspresi diam merupakan langkah awal dimana siswa membiarkan pikiran untuk istirahat dan mencoba memunculkan ide. Hal ini sesuai dengan pendapat Cropley dan Urban (2000) bahwa tahap inkubasi adalah tahap pada saat siswa menyusun hubungan ide penyelesaian dari ide-ide yang pernah ia dapatkan sebelumnya.

Pada tahap iluminasi, siswa mendapatkan ide atau strategi untuk memecahkan masalah yang dituangkan langsung pada kertas yang disediakan. Hal ini juga terjadi pada penelitian yang dilakukan oleh Saefudin (2012) yang menyimpulkan bahwa pada saat menerapkan ide, siswa dengan kemampuan matematika tinggi tidak melakukan kesalahan dalam penyelesaian soal, dan merasa tertantang menyelesaikan soal dengan beragam cara dan jawaban. Pada tahap verifikasi siswa menguji dan mempertimbangkan hal-hal yang diangggap relevan dengan memperhatikan kembali soal, serta memeriksa kembali ide yang diperolehnya sebelum mengambil keputusan. Siswa kategori tinggi cenderung hati-hati dalam menyimpulkan keputusan, ia memeriksa kembali proses penyelesaiannya agar tidak terjadi kesalahan.

Proses berpikir kreatif siswa dalam memecahkan masalah matematika pada siswa kategori sedang. Pada tahap persiapan, siswa mencoba memahami permasalahan, akan tetapi mereka kurang 
memahami informasi atau petunjuk yang diberikan pada soal. Siswa menggaruk-garukkan kepalanya lalu mencoba memahami lagi permasalahan dengan membaca ulang soal. Hal ini sesuai dengan penelitian yang dilakukan oleh Wulantina dkk (2015) siswa dengan kemampuan sedang siswa berusaha menggali informasi, mengidentifikasi masalah yang ditanyakan dengan baik namun kurang konsisten dalam memilih informasi yang dibutuhkan dan informasi yang tidak dibutuhkan dalam penyelesaian masalah. Pada tahap inkubasi siswa berhenti sejenak, mencoba mengingat apa yang telah dipelajari untuk menemukan solusi dari permasalahan yang dihadapi, serta membutuhkn waktu yang lama dalam memikirkan solusi permasalahan. Hal ini sesuai dengan penelitian yang dikemukakan (2014) menyatakan bahwa siswa kurang kreatif tidak mencoba untuk melepaskan diri dari masalah yang sedang dihadapi, namun mencoba untuk memikirkan solusi dari masalah yang dihadapi. Pada tahap Iluminasi siswa menghasilkan ide yang dilahirkan dari pemikirannya dari tahap inkubasi dan dituliskan langsung pada kertas yang telah disediakan. Selanjutnya pada tahap verifikasi, siswa cenderung tidak memeriksa kembali jawaban yang telah dikerjakannya. Berdasarkan teori hipotetik yang disusun oleh Siswono dan Kurniawati (2004) menyimpulkan bahwa siswa kurang kreatif cenderung tidak memeriksa jawabannya setelah selesai mengerjakan tugas.

Proses berpikir kreatif siswa dalam memecahkan masalah matematika pada siswa kategori rendah. Pada tahap persiapan, siswa tidak memiliki persiapan untuk memecahkan masalah, mereka tidak memahami permasalahan yang diberikan. Hal ini sesuai dengan penelitian Defitriani (2014) menyimpulkan bahwa siswa tidak kreatif berusaha untuk memahami masalah yang dihadapainya, namun pemahamannya kurang tepat. Pada tahap inkubasi siswa membutuhkan waktu yang lama untuk memikirkan solusi dari permasalahan, bahkan siswa beralih ke soal yang lainnya. Kemudian pada tahap iluminasi, siswa memberikan jawaban yang sederhana, sesuai pemahaman mereka terhadap permasalahan yang diberikan. hal ini sesuai dengan penelitian yang dilakukan Siswono (2004) yang menyatakan bahwa siswa tidak kreatif yakin dengan ide yang mereka punya, tetapi dalam menyelesaikan soal mereka melakukan kesalahan. Pada tahap verifikasi, siswa tidak memeriksa kembali jawaban yang sudah dikerjakan. Hal ini disebabkan siswa pada kategori rendah, tidak 
mengingat informasi yang diajarkan dengan baik dikarenakan mereka jarang untuk mengulang pelajaran di rumah dan juga jarang melatih diri sendiri untuk mengulang soal-soal yang telah diberikan. Sesuai dengan yang dikatakan Soekamto dan Udin (1997) bahwa seseorang dapat melupakan informasi yang telah diperoleh karena ia gagal untuk merubah ingatan jangka pendek menjadi ingatan jangka panjang karena kurang adanya pengulangan atau karena dia tidak dapat mengelompokkan informasi yang diperolehnya.

\section{Simpulan}

Berdasarkan hasil penelitian dan pembahasan, diperoleh kesimpulan sebagai berikut:

1. Proses berpikir kreatif siswa dalam memecahkan masalah matematika pada siswa kategori tinggi melalui keempat tahap, yaitu tahap persiapan, inkubasi, iluminasi, dan verifikasi. Pada tahap persiapan siswa memahami permasalahan dan mengetahui informasi yang diberikan, terlihat siswa menuliskan informasi yang diberikan dengan bahasanya sendiri. Pada tahap inkubasi siswa memikirkan solusi dari permasalahan yang dihadapi, tidak membutuhkan waktu yang lama untuk memikirkan solusi permasalahan yang dihadapi dengan mengingat materi-materi yang sudah diajarkan. Pada tahap iluminasi, siswa menemukan ide untuk memecahkan masalah, dan menguji ide yang diperolehnya untuk menghasilkan solusi untuk mendapatkan jawaban yang relevan dengan permintaan soal, hal ini merupakan dari tahap verifikasi.

2. Proses berpikir kreatif siswa pada kategori sedang dalam memecahkan masalah matematika melalui tiga tahap proses berpikir kreatif, yaitu tahap persiapan, inkubasi dan iluminasi. Pada tahap persiapan, siswa mencoba memahami permasalahan, dengan membaca beberapa kali permasalahan. Akan tetapi mereka kurang memahami informasi atau petunjuk yang diberikan pada soal. Pada tahap inkubasi siswa mencoba mengingat apa yang telah dipelajari untuk menemukan solusi dengan memperhatikan soal berkali-kali. Pada tahap iluminasi siswa menemukan ide yang dilahirkan dari pemikirannya pada tahap inkubasi untuk memecahkan permasalahan yang dihadapi. Pada tahap verifikasi, siswa cenderung tidak mengecek 
kembali jawaban yang sudah dikerjakan karena siswa sudah meyakini jawaban yang telah diselesaikan.

3. Proses berpikir kreatif siswa pada kategori rendah, pada tahap persiapan, tidak memahami permasalahan yang diberikan dan tidak mengetahui informasi yang diberikan untuk menyelesaikan permasalahan, sehingga pada tahap inkubasi siswa membutuhkan waktu yang lama untuk memikirkan solusi dari permasalahan, bahkan siswa beralih ke soal yang lainnya. Kemudian pada tahap iluminasi, siswa menghsilkan ide yang sederhana, sesuai pemahaman siswa terhadap permasalahan yang ia pahami. Pada tahap verifikasi siswa tidak mengecek kembali solusi yang telah didapatkan karena ia hanya menguji jawaban yang ia tidak pahami.

Saran dari penelitian ini adalah guru hendaknya membimbing siswa dengan memberikan soal-soal pemecahan masalah yang lebih bervariasi sehingga siswa akan lebih terbiasa untuk berpikir kreatif, serta membimbing siswa secara terus menerus agar siswa terbiasa untuk menyelesaikan soal-soal pemecahan masalah dari yang paling mudah.

\section{Daftar Pustaka}

Cropley, A.J. \& Urban, K. K. (2000). Programs and strategies for nurturing creativity. in K. A. Heller, f. J. Monks, R. J. Sternberg \& R. F. Subotnik (Eds.), International Handbook of Research and Development of Giftedness and Talent. Oxford, UK: Pergamon.

Defitriani, E. (2014). Profil berpikir kreatif siswa kelas akselerasi dalam memecahkan masalah matematika terbuka. Jurnal Penelitian Matematika, 6 (2), $65-76$.

Haylock, D. (1997). Recognising mathematical creativity in school children. Electronic Edition ISSN 1615-679X. 29 (3). Diakses di http://www.fiz.karlsruhe.de/fiz/publications/zdmZDM

Kaur, B. (1997). Difficulties problem solving in mathematics. Journal for Research in Mathematics Education, 2 (1), 93-112.

Krulik, S \& Rudnick, J. A. (1995). The new sourcebook for teaching reasoning and problem solving in elementary school. Needham Heights, Massachusetts: Allyn \& Bacon.

Munandar, U. (2009). Pengembangan kreativitas anak berbakat. Jakarta: Rineka Cipta.

OECD. (2016). PISA 2015 Results in focus. Canada: OECD. 
Pehkonen, E. (1999). Fostering of mathematical creativity. Zentralblatt fuer Didaktik der Mathematik (The International Journal on Mathematics Educatio), 3, 63-67.

Saefudin, A.A. (2011). Proses berpikir kreatif siswa sekolah dasar (SD) berkemampuan matematika tinggi dalam pemecahan masalah matematika terbuka. Universitas PGRI Yogyakarta. Yogyakarta. ISBN: 978-979-16353-6-3.

Siswono, T.Y.E. \& Kurniawati, Y. (2004). Penerapan model wallas untuk mengidentifikasi proses berpikir kreatif siswa dalam pengajuan masalah matematika dengan informasi berupa gambar. Diakses di https://www.academia.edu/4068836/PENERAPAN MODEL WALLAS U NTUK MENGIDENTIFIKASI PROSES BERPIKIR KREATIF SISWA DALAM PENGAJUAN MASALAH MATEMATIKA DENGAN INFORMASI BERUPA GAMBAR

Siswono, T.Y.E. (2004). Identifikasi proses berpikir kreatif siswa dalam pengajuan masalah (problem posing) matematika berpandu dengan model Wallas dan Creative Problem Solving (CPS). Buletin Pendidikan Matematika FKIP UNPATTI Ambon, 6 (2), 1-16.

Siswono, T.Y.E., Rosyidi, \& Haris, A. (2005). Menilai kreativitas siswa dalam matematika. Proseding Seminar Nasional Matematika dan Pendidikan Matematika di Jurusan Matematika FMIPA Unesa, 28 Pebruari 2005.

Soekamto, T \& Udin, S. (1997). Teori belajar dan model-model pembelajaran. Jakarta: Universitas Terbuka

Wallas, G. (1926). The art of thought. London, UK: Jonathan Cape.

Wulantina, E, Kusmayadi, T.A, \& Riyadi. (2015). Proses berpikir kreatif siswa dalam pemecahan masalah matematika ditinjau dari kemampuan matematika pada siswa kelas X MIA SMAN 6 Surakarta. Jurnal Elektronik Pembelajaran Matematika. 3 (6), 671-682. 